\title{
Nelfinavir Mesylate
}

National Cancer Institute

\section{Source}

National Cancer Institute. Nelfinavir Mesylate. NCI Thesaurus. Code C1624.

The mesylate salt form of nelfinavir, a synthetic antiviral agent that selectively binds to and inhibits human immunodeficiency virus (HIV) protease. Nelfinavir has activity against HIV 1 and 2. 